Scientific article

Volumen 32(3):701-718. Septiembre-diciembre, 2021 e-ISSN 2215-3608, doi:10.15517/am.v32i3.44498

https://revistas.ucr.ac.cr/index.php/agromeso/index

\title{
Performance of Mesoamerican bean (Phaseolus vulgaris L.) lines in an unfertilized oxisol ${ }^{1}$
}

\section{Comportamiento de líneas mesoamericanas de frijol (Phaseolus vulgaris L.) en un oxisol no fertilizado}

\author{
James S. Beaver ${ }^{2}$, Abiezer González-Vélez², Giovanni Lorenzo-Vázquez, ${ }^{3}$ Raul Macchiavelli², Timothy G. Porch ${ }^{3}$, \\ Consuelo Estevez-de-Jensen ${ }^{2}$
}

1 Reception: 19 de noviembre, 2020. Acceptance: 22 de marzo, 2021. Partial work of the Master of Science degree thesis of the third author conducted at the Universidad de Puerto Rico, Mayagüez, Puerto Rico. Funding for this study was provided by USAID, Feed the Future Legume Innovation Lab for Climate Resilience in Beans, Project AID-OAA-A-13-00077.

2 Universidad de Puerto Rico, Agricultural Experiment Station, P.O. Box 9000, Mayagüez, Puerto Rico 00681-9000. james.beaver@upr.edu (Corresponding author; https://orcid.org/0000-0002-1112-8224), abiezer.gonzalez@upr.edu (https://orcid.org/0000-0001-9169-1350), raul. macchiavelli@upr.edu (https://orcid.org/0000-0002-3727-6874), consuelo.estevez@upr.edu (https://orcid.org/0000-0001-9984-3670).

3 United States Department of Agriculture (USDA) - Agricultural Research Service (ARS), Tropical Agriculture Research Station, 2200 P.A. Campos Ave, Suite 201, Mayagüez, Puerto Rico 00680. giovanni.lorenzo@usda.gov (https://orcid.org/0000-0002-7424-7490), timothy. porch@usda.gov (https://orcid.org/0000-0002-5107-2448).

\begin{abstract}
Introduction. Common beans (Phaseolus vulgaris L.) in Central America and the Caribbean are often produced on low fertility soils which reduces crop yield. Bean breeding programs need to identify genotypes that have superior adaptation to these conditions. Objective. Identify Mesoamerican bean germplasm lines with superior adaptation to low soil fertility. Materials and methods. The performance of twenty-seven Mesoamerican bean (Phaseolus vulgaris L.) lines from the Bean Abiotic Stress Evaluation (BASE) 120 panel were evaluated in an unfertilized oxisol at Isabela, Puerto Rico over five growing seasons (four-year period from 2015-2018). The lines were inoculated with a mixture of Rhizobium etli and R. tropici to promote symbiotic nitrogen fixation (SNF). Results. Four lines produced mean seed yields $>1,200 \mathrm{~kg} \mathrm{ha}^{-1}$ and had estimates of nitrogen derived from the atmosphere (NDFA) $>50 \%$. Greater nodule number was positively correlated with $\%$ NDFA, later maturity and seed yield. The heat and drought tolerant small red cultivar 'Rojo Chortí' and the heat tolerant white cultivar 'Verano' had among the smallest apparent C isotope discrimination values suggesting greater water use efficiency. Among the elite lines in the trial, root rot damage was minimal and the basal root growth angles were intermediate (40-60\%), which favored the uptake of water and soil nutrients. Conclusion. Mesoamerican bean lines with superior seed yield and enhanced symbiotic nitrogen fixation in a low fertility soil were identified. Many of these lines also possess resistance to other biotic and abiotic factors that limit bean seed yield in Central America and the Caribbean.
\end{abstract}

Keywords: plant breeding, soil fertility, symbiotic nitrogen fixation, Rhizobium, carbon isotope discrimination. 


\section{Resumen}

Introducción. El frijol común (Phaseolus vulgaris L.) en América Central y el Caribe a menudo se produce en suelos de baja fertilidad que reduce el rendimiento del cultivo. Los programas de mejoramiento de frijoles necesitan identificar genotipos que tengan una adaptación superior a estas condiciones. Objetivo. Identificar líneas de germoplasma de frijol mesoamericano con una adaptación superior a la baja fertilidad del suelo. Materiales y métodos. El comportamiento de veintisiete líneas de frijol mesoamericano (Phaseolus vulgaris L.) del Vivero de Adaptación de Frijol a Estreses Abióticos (BASE 120), fue evaluado en un oxisol sin fertilizante químico en Isabela, Puerto Rico, durante cinco épocas de siembra (periodo de cuatro años de 2015-2018). Las líneas se inocularon con una mezcla de Rhizobium etli y $R$. tropici para promover la fijación simbiótica de nitrógeno (SNF). Resultados. Cuatro líneas produjeron rendimientos promedios de semilla $>1200 \mathrm{~kg} \mathrm{ha}^{-1} \mathrm{y}$ presentaron estimaciones de nitrógeno derivado de la atmósfera (NDFA) >50 \% . El mayor número de nódulos se correlacionó positivamente con \% NDFA, días a la madurez y rendimiento de semilla. El cultivar rojo pequeño tolerante al calor y la sequía 'Rojo Chortí' y el cultivar blanco 'Verano' tolerante al calor, presentaron los valores de discriminación de isótopos de C más bajos que sugieren una mayor eficiencia en el uso del agua. El daño por pudrición de la raíz fue mínimo y los ángulos de crecimiento basal de la raíz fueron intermedios (40-60 \%), lo que favoreció la absorción de agua y nutrientes del suelo en las líneas élites del ensayo. Conclusión. Se identificaron líneas de frijol mesoamericanas con un rendimiento superior y una mejor fijación simbiótica de nitrógeno en un suelo de baja fertilidad. Algunas líneas también poseen resistencias a otros factores bióticos y abióticos que limitan el rendimiento de semilla de frijol en Centroamérica y el Caribe.

Palabras clave: fitomejoramiento, fertilidad del suelo, fijación simbiótica de nitrógeno, Rhizobium, discriminación de isótopos de carbono.

\section{Introduction}

The production of Mesoamerican (black, small red, and white) beans (Phaseolus vulgaris L.) in Central America and the Caribbean (CAC) is threatened by several diseases and pests including Bean golden yellow mosaic virus, Bean common mosaic virus, Bean common mosaic necrosis virus, rust caused by Uromyces appendiculatus (Pers.: Pers.) Unger, common bacterial blight caused by Xanthomonas axonopodis pv. phaseoli and leafhoppers (Empoasca spp.) (Beaver et al., 2003; Rosas et al., 2000; Rosas, 2011). Considerable progress has been made within the region in the development and release of Mesoamerican bean cultivars having enhanced levels of disease resistance to these and other biotic constraints (Beaver et al., 2018a, 2018b; Porch et al. 2014; Rosas et al., 2004). Bean producers in Central America and the Caribbean also face numerous abiotic yield constraints including terminal drought, high temperatures, and infertile soils (Miklas et al., 2006). Beans in Latin America and the Caribbean are often produced by farmers with limited resources on degraded soils that are deficient in $\mathrm{N}$ (Beebe et al., 2012). Low levels of soil P can reduce nodule numbers and increase the proportion of nodules that are ineffective for symbiotic $\mathrm{N}_{2}$ fixation (SNF) (Pereira \& Bliss, 1987).

The combination of enhanced SNF with the capacity to better acquire or utilize soil $\mathrm{N}$ should improve adaptation of beans to unfertile soils. Bean genotypes that combine greater SNF and nitrogen use efficiency would reduce both dependence on $\mathrm{N}$ fertilizer and potential contamination of $\mathrm{N}$ in the environment (Akter et al., 2018).

Among the grain legumes, common bean has the lowest levels of SNF with an average percentage of nitrogen derived from the atmosphere (NDFA) of $40 \%$ (Herridge et al., 2008). Nitrogen fixation in common bean can be limited by energy supply to the nodules (Graham et al., 2003). Assuming that additional factors such as low soil $\mathrm{P}$ are not limiting, bean lines in low $\mathrm{N}$ soils that have greater \%NDFA may have the capacity to partition greater 
amounts of photosynthate to roots. This may lead to a temporary deficiency in the availability of photosynthates for growth and development of the aerial portion of the plant (Oldroyd \& Leyser, 2020). Chlorotic leaves are a common symptom of soil $\mathrm{N}$ deficiency. A positive correlation has been reported between leaf $\mathrm{N}$ content and SPAD scores in bean leaves at the V4 stage (vegetative) of development (Abrahão et al., 2013). A positive association between SPAD at flowering and \%NDFA was reported in field trials conducted in Ontario, Canada (Farid et al., 2017).

Although efforts to improve symbiotic nitrogen capacity of beans have been successful, the time and cost of phenotypic screening limits routine selection for this complex trait (Kamfwa et al., 2015). Indirect selection for enhanced symbiotic nitrogen fixation might be possible when breeding lines are evaluated in low $\mathrm{N}$ soils. Because bean breeding programs in Central America and the Caribbean often screen lines on research stations and farms having poor soil fertility, some selection of bean lines having improved SNF or greater acquisition of nutrients from the soil may have occurred (Graham et al., 2003). Under drought conditions, bean genotypes that combine high seed yield and larger $\Delta^{13} \mathrm{C}$ values often have deeper roots and lower water use efficiency and may represent the "water user" response to drought stress (Polania et al., 2016a; Sanz-Saez et al., 2019).

This study evaluated the performance of a group of elite Mesoamerican bean breeding lines and cultivars that were selected, in large part, for disease resistance in an unfertilized oxisol at Isabela, Puerto Rico having low levels of soil $\mathrm{N}$. The objective of this research was to identify elite Mesoamerican bean germplasm with superior adaptation to low soil fertility. This germplasm can be used as parents for the continued genetic improvement of Mesoamerican beans for Central America and the Caribbean.

\section{Materials and methods}

The performance of twenty-seven elite lines of common bean (Phaseolus vulgaris L.) from the Bean Abiotic Stress Evaluation (BASE) 120 panel (Oladzad et al., 2019) was evaluated at the Isabela Substation of the Agricultural Experiment Station of the University of Puerto Rico over a four-year period (2015 to 2018). The Substation is located on the northwestern coastal plain of Puerto Rico at $18.468 \mathrm{~N},-67.042 \mathrm{~W}$ at an altitude of 128 $\mathrm{m}$. The average annual minimum and maximum temperatures at the Isabela Experimental Substation are 22.2 and $27.8^{\circ} \mathrm{C}$, with an average annual rainfall of $1,630 \mathrm{~mm}$.

The soil where the field trials were performed is a Coto Clay, a very fine, kaolinitic, isohyperthermic Typic Eutrustox. Soil samples were taken from sites where the BASE 120 trials were conducted. Soil sampling consisted of taking samples at different points in the experimental sites using a zig-zag sampling pattern. A soil sampling tube was used to take sub-samples at a depth of $30 \mathrm{~cm}$ in the soil. The top $5 \mathrm{~cm}$ of soil was removed to eliminate plant material that could contaminate the sample. The subsamples were mixed to prepare a composite sample for each site. The soil chemical analyses were performed at AgSource Harris Laboratories in Lincoln, NE, to determine the availability of soil nutrients (Table 1). Soil $\mathrm{pH}$ was measured in a 1:1 soil:water ratio; soil organic matter was measured by loss on ignition; available phosphorus was extracted with Bray 1 if $\mathrm{pH}$ was $\leq 7.2$, followed by quantification with Inductively Coupled Plasma Spectroscopy (ICP) and exchangeable cations (potassium), using ammonium acetate extraction followed by quantification with ICP.

The trials were conducted at the Isabela Substation during five growing seasons. The trials were planted in June and November 2015, June 2016, June 2017, and June 2018. In order to evaluate the ability of bean genotypes to nodulate and establish symbiotic nitrogen fixation in a soil having low $\mathrm{N}$ fertility, no fertilization was applied to the BASE 120 trials.

Except for the June 2017 planting date, field trials included 118 common bean genotypes and two tepary bean (Phaseolus acutifolius L.) lines from the BASE 120 panel (Tables 2 and 3). The June 2017 planting included 27 elite lines from the BASE 120 panel. Entries in the BASE 120 panel included elite bean breeding lines and cultivars 
Table 1. Results from soil tests from the sites where the tests were carried out with bean (Phaseolus vulgaris L.) lines of the Bean Abiotic Stress Evaluation panel (BASE 120) trials. Isabela, Puerto Rico, from 2015 to 2018.

Cuadro 1. Resultados de los análisis de suelo de los sitios donde se realizaron los ensayos con líneas de frijol (Phaseolus vulgaris L.) del Panel de Evaluación de Estreses Abióticos del Frijol (BASE 120). Isabela, Puerto Rico, entre 2015 y 2018.

\begin{tabular}{llcccc}
\hline Trial planting date & $\mathbf{p H}$ & $\begin{array}{c}\text { Organic matter } \\
\mathbf{- \%}\end{array}$ & Nitrate & $\begin{array}{c}\text { Phosphorus } \\
\mathbf{- p p m - ~}\end{array}$ & Potassium \\
\hline Jun. 2015 & 6.6 & 4.4 & 23.0 & 16.6 & 239 \\
Nov. 2015 & 6.6 & 4.2 & 8.0 & 11.3 & 177 \\
Jun. 2016 & 5.7 & 4.1 & 4.1 & 7.4 & 93 \\
Jun. 2017 & 7.2 & 4.4 & 1.0 & 18.3 & 176 \\
Jun. 2018 & 6.6 & 3.9 & 11.0 & 4.2 & 59 \\
\hline
\end{tabular}

Table 2. Seed type, pedigree, and traits of elite bean (Phaseolus vulgaris L.) lines from the Bean Abiotic Stress Evaluation panel (BASE 120) evaluated in Isabela, Puerto Rico, over five planting dates between 2015 to 2018.

Cuadro 2. Tipo de semilla, pedigrí y características de líneas élite de frijol (Phaseolus vulgaris L.) del Panel de Evaluación de Estreses Abióticos del Frijol (BASE 120) evaluadas en Isabela, Puerto Rico, durante cinco fechas de siembra, entre 2015 y 2018.

\begin{tabular}{|c|c|c|c|c|}
\hline Line & Seed type & Pedigree & Traits & Reference \\
\hline TARS-MST1 & Black & 'Negro Tacana'/VAX 6 & $\begin{array}{l}I, \text { SAP6, SU91, heat and drought } \\
\text { tolerance, root rot resistance }\end{array}$ & Porch et al. (2012) \\
\hline PR1418-15 & Black & PR0443-151/'Verano' & Low soil fertility tolerance & $\begin{array}{l}\text { Granadino-Espinal \& } \\
\text { León-Gonzalez (2016) }\end{array}$ \\
\hline PR1483-105 & Black & 'Verano'//DPC-40/'Zorro' & bgm-1, SW12, I & $\begin{array}{l}\text { Granadino-Espinal \& } \\
\text { León-Gonzalez (2016) }\end{array}$ \\
\hline PR1147-1 (Hermosa) & Black & $\begin{array}{l}\text { 'Negro Veracruz' / PR9607-29// } \\
\text { 'VAX } 6 \text { / MUS } 83 \text { // DOR482 } \\
\text { / BAT 93' }\end{array}$ & bgm-1, SW12, I, bc-3 & Beaver et al. (2018) \\
\hline B12724 & Black & B09184/B09135 & I, SU91 & \\
\hline BIOF 4-70 & Black & G23818B/EAP9503-32B & $\begin{array}{l}\text { bgm-1, SW12, I, low soil } \\
\text { fertility tolerance }\end{array}$ & \\
\hline 'Sayaxché' & Black & $\begin{array}{l}\text { DOR 390/'Tío Canela 75'// } \\
\text { SRC1-1-18/'Milenio' }\end{array}$ & $\begin{array}{l}\text { bgm-1, SW12, I, low soil } \\
\text { fertility and drought tolerance }\end{array}$ & $\begin{array}{l}\text { Instituto de Ciencia y } \\
\text { Tecnología Agrícolas } \\
(2010)\end{array}$ \\
\hline MHN 322-49 & Black & 'ICTA Ligero'/MH2-2 & $\begin{array}{l}\text { bgm-1, SW12, I, ashy stem } \\
\text { blight and common bacterial } \\
\text { blight resistance, drought } \\
\text { tolerance }\end{array}$ & \\
\hline $\begin{array}{l}\text { 'Sankara'('Azabache } \\
40 \text { ') }\end{array}$ & Black & $\begin{array}{l}\text { DOR483/BelNeb RR-2// } \\
\text { MUS83/DOR483///'Raven', }\end{array}$ & $\begin{array}{l}b g m-1, \mathrm{SW} 12, I, b c-3 \text {, angular } \\
\text { leaf spot resistance }\end{array}$ & $\begin{array}{l}\text { Beaver et al. (2014) } \\
\text { Rosas et al. (2016) }\end{array}$ \\
\hline PR1165-3 & Black & DPC-40/'Zorro' & $\begin{array}{l}b g m-1, I, b c-3, \text { long and dense } \\
\text { root hairs }\end{array}$ & \\
\hline 'Beníquez' & White & $\begin{array}{l}\text { DOR483/BelNeb RR-2// } \\
\text { MUS83/DOR483///'Raven' }\end{array}$ & $\begin{array}{l}b g m-1, \mathrm{SW} 12, I, \quad b c-3 \text {, heat } \\
\text { tolerance }\end{array}$ & Beaver et al. (2011) \\
\hline 'ICA Pijao’ & Black & $\begin{array}{l}\text { CIAT germplasm G5773 from } \\
\text { Colombia }\end{array}$ & $I$, symbiotic nitrogen fixation & \\
\hline 'Lenca Precoz' & Black & 'ICTA Ligero'/’Raven' & $\begin{array}{l}\text { bgm-1, SW12, I, } b c-3 \text {, early } \\
\text { maturity, drought tolerance }\end{array}$ & Rosas et al. (2016) \\
\hline
\end{tabular}


Table 3. Seed type, pedigree, and traits of elite bean (Phaseolus vulgaris L.) lines from the Bean Abiotic Stress Evaluation panel (BASE 120) evaluated in Isabela, Puerto Rico, over five planting dates between 2015 to 2018.

Cuadro 3. Tipo de semilla, pedigrí y características de líneas élite de frijol (Phaseolus vulgaris L.) del Panel de Evaluación de Estreses Abióticos del Frijol (BASE 120) evaluadas en Isabela, Puerto Rico, durante cinco fechas de siembra entre 2015 y 2018.

\begin{tabular}{|c|c|c|c|}
\hline Line & Seed type & Pedigree & Traits (References) \\
\hline 'Bella' & White & 'Verano'//PR0003-124/'Raven' & $\begin{array}{l}\text { bgm- } 1, \mathrm{SW} 12, I, b c-3 \text {, common blight } \\
\text { resistance (Beaver et al., 2018a) }\end{array}$ \\
\hline SB2-170 & Cream & $\begin{array}{l}\text { 'Matterhorn'/G21212///'Matterhorn'/ } \\
\text { DOR 364//USPT-ANT1/H405-8-1-1 }\end{array}$ & Drought tolerance \\
\hline $\begin{array}{l}\text { Paisano PF } \quad \text { (MER } \\
\text { 2212-28) }\end{array}$ & Small red & 'Milenio'/'Amadeus 77' & bgm-1, SW12, I, heat tolerance \\
\hline FBN 1203-43 & Small red & $\begin{array}{l}\text { 'Amadeus 77'//'Amadeus77'/'Paraisito' } \\
\text { ///'Amadeus 77'/IBC 306-55 }\end{array}$ & $\begin{array}{c}\text { bgm-1, SW12, I, SNF, long and dense root } \\
\text { hairs }\end{array}$ \\
\hline $\begin{array}{l}\text { 'INTA Centro Sur' } \\
\text { (IBC 301-204) }\end{array}$ & Small red & 'Amadeus 77'//'Amadeus 77'/'Paraisito' & $\begin{array}{l}\text { bgm-1, SW12, I, SNF, low soil fertility } \\
\text { tolerance }\end{array}$ \\
\hline TARS-LFR1 & Small red & $\begin{array}{l}\text { BAT 477/VAX 2//BAT 477/VAX 1/3/ } \\
\text { VAX } 3 \text { using recurrent selection }\end{array}$ & $\begin{array}{l}\text { I, root rot resistant, SNF, low soil fertility } \\
\text { tolerance (Porch et al., 2014) }\end{array}$ \\
\hline $\begin{array}{l}\text { 'CENTA Pipil' ('Rojo } \\
\text { INIFAP') }\end{array}$ & Small red & 'Bribrí'/MD 30-37//RS3 & $\begin{array}{l}\text { bgm-1, SW12, I, heat tolerance (Centro } \\
\text { Nacional de Tecnología Agropecuaria y } \\
\text { Forestal, 2005; Villar-Sánchez et al., 2010) }\end{array}$ \\
\hline SER 118 & Small red & SXB 123/EAP9503-32B//RCB137 & $\begin{array}{l}\text { Drought tolerance, superior performance in } \\
\text { low P soils }\end{array}$ \\
\hline FBN $1203-47$ & Small red & $\begin{array}{c}\text { 'Amadeus 77'//'Amadeus77'/'Paraisito' } \\
\text { ///'Amadeus 77'/IBC 306-55 }\end{array}$ & bgm-1, SW12, I, SNF \\
\hline $\begin{array}{l}\text { 'Rojo Chortí'('CENTA } \\
\text { EAC') }\end{array}$ & Small red & 'Negro Vaina Blanca'/BCN 20-0294 & $\begin{array}{c}\text { bgm-1, SW12, I, heat tolerance (Rosas et al., } \\
\text { 2019; Parada-Cardona et al., 2015) }\end{array}$ \\
\hline BAT 477 & Cream & 51052/ICA Bunsi//51052/Cornell 49-242 & $\begin{array}{c}I, \text { tolerance to low soil fertility, root rot } \\
\text { resistance, plastic gravitropic root systems - } \\
\text { shallower root systems in low P soils (Liao et } \\
\text { al., 2001) }\end{array}$ \\
\hline 'Verano' & White & $\begin{array}{l}\text { DOR 364/WBB-20-1//‘Don Silvio’/ } \\
\text { VAX } 6\end{array}$ & $\begin{array}{l}\text { bgm-1, SW12, I, common blight resistance } \\
\text { (Beaver et al., 2008) }\end{array}$ \\
\hline 'Beníquez' & White & $\begin{array}{l}\text { DOR483/BelNeb RR-2//MUS83/ } \\
\text { DOR483///'Raven' }\end{array}$ & $\begin{array}{c}\text { bgm-1, SW12, I, bc-3, heat tolerance (Beaver } \\
\text { et al., 2011) }\end{array}$ \\
\hline $\begin{array}{l}\text { 'Paraisito Mejorado 2- } \\
\text { Don Rey' }\end{array}$ & Small red & 'Carrizalito’ *2/'Paraisito' & $\begin{array}{l}\text { bgm-1, SW12, I, tolerance to drought and low } \\
\text { soil fertility tolerance (Rosas, 2015) }\end{array}$ \\
\hline SEF 16 & Small red & ALB 74/INB 841//RCB 593 & $\begin{array}{l}\text { bgm-1, I, terminal drought and heat tolerance } \\
\text { (Chaves-Barrantes, 2015) }\end{array}$ \\
\hline
\end{tabular}

from Zamorano University in Honduras, the International Center for Tropical Agriculture (CIAT), the University of Puerto Rico, USDA-ARS Tropical Agriculture Research Station and Michigan State University.

Although no fertilizer was applied in the elite BASE 120 trials, the lines were inoculated with two strains of Rhizobium; R. etli (CIAT 632) and R. tropici (CIAT 899), that was prepared at the Juana Diaz Station Laboratory. During the June 2015 planting date, a liquid suspension of inoculum at a concentration of $10^{7}$ rhizobia cells per $\mathrm{mm}$ was applied first directly to the seeds in the row and, after emergence, to the base of the seedlings using a backpack sprayer. The estimated amount of liquid inoculant was based on the volume recommended for $50 \mathrm{~kg}$ of seeds and 14 seeds per $\mathrm{m}$. The inoculation for the other growing seasons was performed using a solid inoculant. 
This peat-based inoculant contained the same two strains of Rhizobium. The procedure consisted of applying 25 $\mathrm{g}$ of Rhizobium inoculant and PREMAX (bacterial protector) per $1 \mathrm{~kg}$ of seeds. The inoculant was applied to each genotype by stirring the inoculant and the seed of each genotype in a plastic container. The inoculant had a concentration of $1 \times 10^{9}$ rhizobia $^{-1}$ peat. When using this inoculation technique, it was necessary to ensure that the seeds were evenly covered by the inoculant. The inoculated seed were stored at room temperature, overnight and planted the following day.

The entries from the BASE 120 trials (Tables 2 and 3) were planted in a randomized complete block design with five replications. The experimental units were single $3 \mathrm{~m}$ rows with $0.76 \mathrm{~m}$ spacing between experimental units. The seeding rate was 14 seeds per $\mathrm{m}$. The field trials received supplementary aerial irrigation to avoid drought stress. Weeds were controlled manually. The trials were monitored twice a week to detect the presence and incidence of pests and diseases. Preventive measures were taken in cases where a high density of pests was found. No fungicides were applied to the field trials.

Nodulation was evaluated during flowering (approximately 45 days after planting) using two plants per experimental unit. Plant root crowns were carefully extracted at about $0.75 \mathrm{~m}$ from the end of each plot. Root crowns were washed to remove the excess soil. Nodule numbers were evaluated by assigning values from 1-9 using the CIAT scale, where 1 represented a plant with $>81$ nodules, 3 had 41-80 nodules, 5 had 21-40 nodules, 7 had 10-20 nodules, and 9 had <10 nodules per plant (van Schoonhoven \& Pastor-Corrales, 1987). The chlorophyll content was measured approximately 45-50 days after planting using a Minolta Chlorophyll Meter SPAD-502 on three randomly chosen central leaves of plants from each experimental unit.

Seed samples from each of three replications of the BASE 120 trials conducted at the Isabela Substation in 2016, 2017, and 2018 were used to estimate percentage of N derived from the atmosphere (\%NDFA) and apparent $\mathrm{C}$ isotope discrimination $\left(\Delta^{13} \mathrm{C}\right)$. Approximately 5 seed of each sample were dried until a constant weight was achieved at $70{ }^{\circ} \mathrm{C}$, and then were ground at the USDA-ARS Tropical Agriculture Research Station using a Wiley mini-mill (Thomas Scientific, Swedesboro, New Jersey, USA), passed through a \#40 mesh sieve, resulting in a fine powder. The $4.2 \mathrm{mg}$ samples were packaged in $5 \times 8 \mathrm{~mm}$ tin capsules (D1008, EA Consumables, Pennsauken, NJ) and shipped to the University of California, Davis Stable Isotope Facility in 96-well plates.

The ${ }^{15} \mathrm{~N}$ natural abundance method (Unkovich et al., 2008) was used to calculate the \%NDFA estimates. The white bean R-99 was used as the non-N-fixing reference line.

$$
\% \mathrm{NDFA}=\left[\left(\Delta{ }^{15} \mathrm{~N} \text { R99 }-\Delta{ }^{15} \mathrm{~N} \text { BASE } 120 \text { line }\right) /\left(\Delta{ }^{15} \mathrm{~N} \text { R99-B }\right)\right] * 100
$$

Where B represents the $\Delta^{15} \mathrm{~N}$ of the bean line grown under $\mathrm{N}$-free conditions and relies on symbiotic nitrogen fixation for all $\mathrm{N}$ requirements. In this study, the variable $\mathrm{B}$ was assigned the value of 0 because the R99 reference line does not nodulate. The entries in the BASE 120 trial and the R99 reference bean line have similar patterns of phenological development and seed size. In a $\mathrm{N}$-free trial conducted by Heilig et al. (2017), no significant differences in $\Delta^{15} \mathrm{~N}$ were found among flowering plants of 'Puebla 152', 'Zorro', 'Medalist', and PR0443-151. Constant B values for seed of 2.44 0/00 for bean genotypes having type II and 2.88 0/00 for genotypes having type III growth habits were used for greenhouse studies conducted by CIAT in Cali, Colombia (Polania et al., 2016b). The use of a constant B value, however, would not change the ranks of \%NDFA estimates among the entries. The size of the B value is less important when \%NDFA estimates are low $(<50 \%)$ (Unkovich, 2008). The ${ }^{15} \mathrm{~N}$ natural abundance method using seed tissue is well-suited for use by a breeding program to screen for superior SNF (Polania et al., 2016b).

Carbon isotope discrimination $\left(\Delta^{13} \mathrm{C}, \%\right)$ estimates were calculated using the following equation:

$$
\Delta{ }^{13} \mathrm{C}=\left(\Delta^{13} \mathrm{C}_{\text {atmosphere }}-\Delta^{13} \mathrm{C}_{\text {sample }}\right) /\left(\Delta^{13} \mathrm{C}_{\text {sample }}+1\right)
$$


Where $\Delta^{13} \mathrm{C}_{\text {atmosphere }}\left(-8 \%\right.$ ) is the $\mathrm{C}$ isotope composition of $\mathrm{CO}^{2}$ in the atmosphere (Farquhar et al., 1989) and $\Delta{ }^{13} \mathrm{C}_{\text {sample }}$ is the $\mathrm{C}$ isotope composition of the seed sample.

Data collected from the 27 lines were used for the analyses. Statistical analysis was performed using a GLIMMIX model from SAS/STAT 14.3 (SAS Institute, Cary, NC) to analyze main effects and interactions and to compare the least squares means. Planting dates and bean genotypes were considered as fixed effects whereas replication was considered a random effect within planting dates. A $95 \%$ probability level was used to establish statistical significance. Pearson correlations were calculated to study associations between least squares means of seed yield and other traits measured in this study.

\section{Results}

Soil $\mathrm{pH}$ in the fields at the Isabela Substation where the BASE 120 trials were conducted ranged from 5.7 to 6.6 and soil organic matter ranged from 3.9 to 4.4 , which are adequate values for normal bean growth and development (Table 1). Three of the planting dates had soil nitrate levels $<10 \mathrm{ppm}$ and a fourth date had $11 \mathrm{ppm}$ of soil nitrate. Results from soil samples taken for the June 2018 planting had a sub-optimum level of P. The soil samples taken for the other planting dates had medium to high levels of $\mathrm{P}$ and $\mathrm{K}$ for dry bean production.

The pedigrees in Tables 2 and 3 show that a diverse group of Mesoamerican parents was used to develop the elite breeding lines in this study. The pedigrees, however, include very few parents from other bean races and no Andean bean parents.

Fourteen of the 27 lines produced mean seed yields $>1,000 \mathrm{~kg} \mathrm{ha}^{-1}$ in un-fertilized trials planted at the Isabela Substation over five growing seasons (Table 4). In order to adapt to existing cropping systems in CAC, the elite lines have Type II and III growth habits and reached harvest maturity from 73.4 to 87.0 days after planting (Table 5).

Significant genotype $x$ season $(\mathrm{G} \times \mathrm{E})$ interactions for seed yield were observed for most bean lines. One of the exceptions was the line SB2-170 that combined a mean seed yield $>1,000 \mathrm{~kg} \mathrm{ha}^{-1}$ and non-significant $\mathrm{G} \times \mathrm{E}$ across environments. The black bean cultivar 'Hermosa' produced among the highest mean seed yields although nodulation scores were poor and \%NDFA estimates were low.

Good root health is needed to efficiently absorb available soil nutrients and water. Mean root rot scores were low $(<3)$ suggesting that the lines had good root health in these trials, thus this was not a factor limiting nutrient uptake (Table 5). Mean basal root growth angle (BRGA) ranged from 54.1 to $64.6 \%$ (Table 5). G×E for BRGA, except for TARS-MST1 and PR1483-105, was non-significant for the higher yielding lines. The eight highestyielding lines also had non-significant G×E for SPAD, \%NDFA, and root rot scores (Table 6).

SPAD scores ranged from 37.1 to 50.1 (Table 6). Five lines had nodulation scores $<6.0$, although the five lines with the highest mean seed yields had nodulation scores $>6.0$ (Table 6 ). In contrast, four of the five lines with the highest seed yields had \%NDFA $>50 \%$ (Table 6).

Seed yield and harvest date were not correlated. Nodulation scores were negatively correlated with harvest date $\left(-0.48^{*}\right)$ but positively associated with seed yield $\left(0.39^{*}\right)$. Thus, the later maturing lines and cultivars in the study tended to have greater nodule numbers although a few of the highest yielding lines had fewer nodules. Nodule number, however, does not reflect the effectiveness of nodules to fix nitrogen. In this study, nodule number and $\%$ NDFA were positively associated reflected by a negative correlation $(-0.40 *)$ between nodulation scores $(1 \geq 81$ and $9<10$ nodules/plant) and \%NDFA estimates. \%NDFA was not significantly associated with days to maturity or seed yield. There was a negative correlation $\left(-0.53^{* *}\right)$ between SPAD scores and \%NDFA. 
Table 4. Least square means of seed yield of elite bean (Phaseolus vulgaris L.) lines from the Bean Abiotic Stress Evaluation panel (BASE 120) evaluated in Isabela, Puerto Rico over five growing seasons from 2015 to 2018.

Cuadro 4. Medias ajustadas de rendimiento de semillas de líneas élite de frijol (Phaseolus vulgaris L.) del Panel de Evaluación de Estreses Abióticos del Frijol (BASE 120), evaluadas durante cinco fechas de siembra en Isabela, Puerto Rico entre 2015 y 2018.

\begin{tabular}{|c|c|c|c|c|c|c|c|c|}
\hline Line & $\begin{array}{c}\text { BASE } \\
120 \text { entry } \\
\text { number }\end{array}$ & June 2015 & Nov. 2015 & June 2016 & June 2017 & June 2018 & Mean & $\begin{array}{c}\text { F Test for season } \\
\text { comparisons } \\
\text { within each line }\end{array}$ \\
\hline Bella & 70 & 1652 & 869 & 1574 & 1329 & 955 & 1276 & $* *$ \\
\hline TARS-MST1 & 111 & 1083 & 902 & 1729 & 1494 & 1024 & 1246 & $* *$ \\
\hline PR1418-15 & 71 & 1606 & 598 & 1732 & 1386 & 889 & 1242 & $* *$ \\
\hline PR1483-105 & 72 & 1418 & 679 & 1725 & 1329 & 978 & 1226 & $* *$ \\
\hline 'Hermosa' & 64 & 1540 & 1020 & 1249 & 1349 & 889 & 1209 & $* *$ \\
\hline B12724 & 6 & 1699 & 412 & 1362 & 1249 & 1295 & 1203 & $* *$ \\
\hline BIOF 4-70 & 20 & 983 & 718 & 1561 & 1428 & 1289 & 1196 & $* *$ \\
\hline SB2-170 & 109 & 1391 & 834 & 1304 & 1093 & 1097 & 1144 & NS \\
\hline 'Sayaxché’ & 78 & 1326 & 641 & 1502 & 1299 & 856 & 1125 & $* *$ \\
\hline MER 2212-28 & 54 & 942 & 723 & 1516 & 1115 & 1302 & 1120 & $* *$ \\
\hline FBN 1203-43 & 36 & 1291 & 365 & 1476 & 1042 & 1205 & 1076 & $* *$ \\
\hline 'INTA Centro Sur' & 44 & 1039 & 603 & 1393 & 1020 & 1286 & 1068 & $* *$ \\
\hline TARS-LFR1 & 110 & 1011 & 799 & 1379 & 1185 & 897 & 1054 & NS \\
\hline 'CENTA Pipil' & 30 & 1246 & 672 & 1404 & 1056 & 852 & 1046 & $* *$ \\
\hline SER 118 & 98 & 449 & 463 & 1681 & 1022 & 1005 & 924 & $* *$ \\
\hline MHN 322-49 & 55 & 807 & 731 & 1095 & 879 & 1096 & 922 & NS \\
\hline 'Sankara' & 118 & 349 & 919 & 1401 & 971 & 844 & 897 & $* *$ \\
\hline FBN 1203-47 & 37 & 919 & 250 & 1190 & 913 & 1199 & 894 & $* *$ \\
\hline 'Rojo Chortí' & 102 & 672 & 347 & 1429 & 886 & 1003 & 867 & $* *$ \\
\hline BAT 477 & 10 & 853 & 428 & 1310 & 930 & 815 & 867 & $* *$ \\
\hline ‘Verano' & 117 & 420 & 724 & 1492 & 979 & 710 & 865 & $* *$ \\
\hline PR1165-3 & 68 & 353 & 497 & 1472 & 824 & 884 & 806 & $* *$ \\
\hline ‘Beníquez' & 12 & 433 & 415 & 1493 & 781 & 584 & 741 & $* *$ \\
\hline 'Paraisito Mej. 2' & 59 & 562 & 330 & 765 & 762 & 789 & 642 & NS \\
\hline SEF 16 & 92 & 347 & & 1202 & 762 & 625 & 635 & $* *$ \\
\hline 'ICA Pijao' & 43 & 396 & 531 & 887 & 630 & 673 & 623 & NS \\
\hline 'Lenca Precoz' & 53 & 429 & 460 & 834 & 565 & 628 & 583 & NS \\
\hline
\end{tabular}

F Tests for comparing season means sliced by lines for bean lines having superior \%NDFA were not significant, suggesting that this trait was stable across environments.

The small red bean, 'Rojo Chortí', consistently had the lowest $\Delta^{13} \mathrm{C}$ CID values over the three growing seasons (Table 7). The black bean lines B12724, PR1165-3, and 'Sankara' had among the largest least squared means for $\Delta^{13} \mathrm{C}$ across growing seasons. The black bean lines TARS-MST1 and B12724 were ranked in the top 6 in seed yield 
Table 5. Least square means of seed yield, SPAD scores, nodulation scores, root rot scores, basal root growth angle (BRGA), and harvest date of elite bean (Phaseolus vulgaris L.) lines from the Bean Abiotic Stress Evaluation panel (BASE 120) evaluated in Isabela, Puerto Rico. 2015-2018.

Tabla 5. Medias ajustadas de rendimiento de semilla, lecturas de pudrición de la raíz, BRGA y fecha de cosecha de líneas élite de frijol (Phaseolus vulgaris L.) del Panel de Evaluación de Estreses Abiótico del Frijol (BASE 120), evaluadas en Isabela, Puerto Rico. 2015-2018.

\begin{tabular}{|c|c|c|c|c|c|c|c|}
\hline \multirow[b]{2}{*}{ Line } & \multirow{2}{*}{$\begin{array}{c}\text { Seed yield }\left(\mathrm{kg} \mathrm{ha}^{-1}\right) \\
\text { Mean }\end{array}$} & \multicolumn{2}{|c|}{ Root rot score } & \multicolumn{2}{|r|}{ BRGA (\%) } & \multicolumn{2}{|r|}{ Harvest date } \\
\hline & & Mean & $\begin{array}{l}\text { F Test for season } \\
\text { comparisons in } \\
\text { each entry }\end{array}$ & Mean & $\begin{array}{l}\text { F Test for season } \\
\text { comparisons in } \\
\text { each entry }\end{array}$ & Mean & $\begin{array}{c}\text { F Test for season } \\
\text { comparisons in } \\
\text { each entry }\end{array}$ \\
\hline 'Bella' & 1276 & 2.1 & NS & 62.8 & NS & 81.0 & $* *$ \\
\hline TARS-MST1 & 1246 & 1.6 & NS & 61.0 & $*$ & & \\
\hline PR1418-15 & 1242 & 2.2 & NS & 57.3 & NS & 80.1 & $* *$ \\
\hline PR1483-105 & 1226 & 2.0 & NS & 58.5 & $*$ & 78.6 & $* *$ \\
\hline 'Hermosa' & 1209 & 1.6 & NS & 60.8 & NS & 75.5 & NS \\
\hline B12724 & 1203 & 2.0 & NS & 59.5 & NS & 81.4 & $* *$ \\
\hline BIOF 4-70 & 1196 & 2.0 & NS & 56.0 & NS & 76.9 & $* *$ \\
\hline SB2-170 & 1144 & 1.8 & NS & 59.8 & NS & 75.2 & NS \\
\hline 'Sayaxché' & 1125 & 1.9 & NS & 62.0 & NS & 81.1 & $* *$ \\
\hline MER 2212-28 & 1120 & 2.0 & $*$ & 62.3 & $*$ & 78.3 & $* *$ \\
\hline FBN 1203-43 & 1076 & 2.0 & $* *$ & 59.2 & NS & 75.0 & $* *$ \\
\hline 'INTA Centro Sur' & 1068 & 2.2 & $*$ & 64.6 & NS & 77.2 & $* *$ \\
\hline TARS-LFR1 & 1054 & 1.7 & NS & 58.8 & NS & & $* *$ \\
\hline 'CENTA Pipil' & 1046 & 2.3 & $*$ & 59.0 & $*$ & 78.0 & \\
\hline SER 118 & 924 & 1.9 & $*$ & 55.5 & NS & 74.8 & $* *$ \\
\hline MHN 322-49 & 922 & 1.5 & NS & 63.5 & NS & 87.0 & $* *$ \\
\hline 'Sankara' & 897 & 2.0 & NS & 55.9 & NS & & \\
\hline FBN 1203-47 & 894 & 2.4 & NS & 59.3 & NS & 76.9 & $* *$ \\
\hline BAT 477 & 867 & 1.8 & NS & 62.2 & NS & 80.4 & $* *$ \\
\hline 'Rojo Chortî' & 867 & 2.2 & $* *$ & 61.8 & $* *$ & 83.7 & NS \\
\hline 'Verano' & 865 & 1.8 & NS & 54.8 & $*$ & & \\
\hline PR1165-3 & 806 & 1.6 & $*$ & 54.1 & $* *$ & 81.3 & $* *$ \\
\hline 'Beníquez' & 741 & 2.1 & NS & 54.2 & $*$ & 83.6 & $* *$ \\
\hline 'Paraisito Mej. 2' & 642 & 1.9 & $* *$ & 61.3 & $*$ & 84.2 & $* *$ \\
\hline SEF 16 & 635 & 1.9 & $*$ & 57.4 & NS & 74.7 & $* *$ \\
\hline 'ICA Pijao' & 623 & 2.1 & NS & 62.7 & NS & 84.5 & $* *$ \\
\hline 'Lenca Precóz' & 583 & 2.1 & NS & 63.7 & NS & 73.4 & $* *$ \\
\hline
\end{tabular}

over 5 growing seasons and showed high $\Delta^{13} \mathrm{C}$ values. The white bean cultivar 'Verano' and the small red breeding line TARS-LFR1 had among the lowest $\Delta^{13} \mathrm{C}$ values across seasons. Both lines were selected in Puerto Rico for adaptation to higher temperatures when daily water demand is the highest, thus lower $\Delta^{13} \mathrm{C}$ values in this study may be associated with water use efficiency. 
Table 6. Least square means of seed yield, SPAD scores, nodulation scores, and \% nitrogen derived from the atmosphere (\%NDFA) of elite bean (Phaseolus vulgaris L.) lines from the Bean Abiotic Stress Evaluation panel (BASE 120) evaluated in Isabela, Puerto Rico, from 2015 to 2018 .

Tabla 6. Medias ajustadas de rendimiento de semilla, lecturas de SPAD, lecturas de nodulación y (\% nitrógeno derivado de la atmósfera (\% NDFA) de líneas élite de frijol (Phaseolus vulgaris L.) del Panel de Evaluación de Estreses Abióticos del Frijol (BASE 120), evaluadas en Isabela, Puerto Rico, entre 2015 y 2018.

\begin{tabular}{|c|c|c|c|c|c|c|c|}
\hline \multirow[b]{2}{*}{ Line } & \multicolumn{2}{|l|}{ Seed yield $\left(\mathrm{kg} \mathrm{ha}^{-1}\right)$} & \multirow{2}{*}{$\begin{array}{c}\text { SPAD score } \\
\begin{array}{c}\text { F Test for season } \\
\text { comparisons in } \\
\text { each entry }\end{array}\end{array}$} & \multicolumn{2}{|c|}{ Nodulation score (1-9) } & \multicolumn{2}{|r|}{ NDFA $(\%)$} \\
\hline & Mean & Mean & & Mean & $\begin{array}{l}\text { F Test for season } \\
\text { comparisons in } \\
\text { each entry }\end{array}$ & Mean & $\begin{array}{c}\text { F Test for season } \\
\text { comparisons in each } \\
\text { entry }\end{array}$ \\
\hline 'Bella' & 1276 & 46.4 & NS & 6.3 & $* *$ & 55.0 & NS \\
\hline TARS-MST1 & 1246 & 40.5 & NS & 7.0 & NS & 53.2 & NS \\
\hline PR1418-15 & 1242 & 40.9 & NS & 6.2 & * & 58.8 & NS \\
\hline PR1483-105 & 1226 & 43.7 & NS & 6.7 & NS & 52.3 & NS \\
\hline 'Hermosa' & 1209 & 48.4 & NS & 7.6 & NS & 23.1 & NS \\
\hline B12724 & 1203 & & NS & 6.8 & $* *$ & 44.6 & NS \\
\hline BIOF 4-70 & 1196 & 38.1 & NS & 7.4 & NS & & \\
\hline SB2-170 & 1144 & 50.1 & NS & 7.5 & NS & 42.7 & NS \\
\hline 'Sayaxché' & 1125 & 46.4 & * & 6.6 & $* *$ & & \\
\hline MER 2212-28 & 1120 & 49.6 & NS & 7.2 & NS & 27.9 & NS \\
\hline FBN 1203-43 & 1076 & 45.4 & NS & 6.9 & NS & 33.8 & NS \\
\hline 'INTA Centro & & & & & & & \\
\hline Sur' & 1068 & 40.3 & NS & 5.9 & ** & 56.0 & NS \\
\hline TARS-LFR1 & 1054 & 40.4 & NS & 6.9 & * & 43.8 & NS \\
\hline ‘CENTA Pipil’ & 1046 & 47.1 & NS & 7.4 & * & 42.1 & NS \\
\hline SER 118 & 924 & 45.9 & NS & 7.5 & * & 39.6 & $* *$ \\
\hline MHN 322-49 & 922 & 44.1 & NS & 6.4 & * & 29.7 & NS \\
\hline 'Sankara' & 897 & 42.6 & NS & 5.7 & * & 37.4 & NS \\
\hline FBN 1203-47 & 894 & 39.8 & NS & 5.9 & NS & 55.1 & NS \\
\hline BAT 477 & 867 & 37.1 & NS & 6.8 & ** & 58.0 & NS \\
\hline ‘Rojo Chortí' & 867 & 45.0 & NS & 6.6 & * & 53.7 & NS \\
\hline 'Verano' & 865 & 48.1 & NS & 6.7 & * & 56.1 & NS \\
\hline PR1165-3 & 806 & 43.0 & NS & 7.2 & ** & 47.5 & NS \\
\hline ‘Beníquez’ & 741 & 41.4 & NS & 5.9 & NS & 49.6 & NS \\
\hline 'Paraisito Mej. & & & & & & & \\
\hline 2 & 642 & 38.0 & NS & 6.3 & $* *$ & & \\
\hline SEF 16 & 635 & 46.4 & NS & 6.9 & $* *$ & 31.8 & NS \\
\hline ‘ICA Pijao’' & 623 & 45.3 & NS & 5.5 & ** & 54.2 & NS \\
\hline ‘Lenca Precóz’ & 583 & 45.5 & NS & 6.3 & $* *$ & 27.3 & $*$ \\
\hline
\end{tabular}

\section{Discussion}

Soil and climatic conditions were suitable in this study to identify Mesoamerican bean lines having superior adaptation to low soil fertility and moderate levels of heat tolerance. Daytime temperatures $>30^{\circ} \mathrm{C}$ and nighttime lows $>20^{\circ} \mathrm{C}$ can reduce bean seed yield (Beebe et al., 2012). On the northern coast of Puerto Rico, from the months of June to October, mean daytime maximum temperatures normally range from $30-31^{\circ} \mathrm{C}$ and nighttime minimum temperatures are often $>25^{\circ} \mathrm{C}$ (National Centers for Environmental Information, 2020). Therefore, lines in the four 
Table 7. Least square means of carbon isotope discrimination of elite bean (Phaseolus vulgaris L.) lines from the Bean Abiotic Stress Evaluation panel (BASE 120), evaluated at Isabela, Puerto Rico, over three growing seasons. 2016-2018.

Tabla 7. Medias ajustadas de discriminación de isótopos de carbono de líneas élite de frijol (Phaseolus vulgaris L.) del Panel de Evaluación de Estreses Abióticos del Frijol (BASE 120), evaluadas en Isabela, Puerto Rico, durante tres fechas de siembra. $2016-2018$.

\begin{tabular}{|c|c|c|c|c|c|c|c|}
\hline Genotype & Entry & June 2016 & Rank & June 2017 & Rank & June 2018 & Rank \\
\hline B12724 & 6 & 22.4 & 22 & 22.3 & 22 & 20.5 & 23 \\
\hline BAT 477 & 10 & 21.8 & 15 & 21.6 & 15 & 18.8 & 7 \\
\hline 'Beníquez' & 12 & 21.6 & 8 & 21.5 & 8 & 19.5 & 18 \\
\hline 'CENTA Pipil' & 30 & 21.0 & 3 & 20.3 & 3 & 19.3 & 12 \\
\hline FBN 1203-43 & 36 & 21.1 & 4 & 20.8 & 4 & 19.3 & 13 \\
\hline FBN 1203-47 & 37 & 21.6 & 9 & 21.0 & 9 & 18.9 & 8 \\
\hline 'ICA Pijao’ & 43 & 21.6 & 10 & 21.5 & 10 & 19.4 & 16 \\
\hline 'INTA Centro Sur' & 44 & 21.6 & 11 & 21.5 & 11 & 19.3 & 14 \\
\hline 'Lenca Precoz' & 53 & 21.7 & 13 & 21.2 & 13 & 20.1 & 19 \\
\hline MER 2212-28 & 54 & 21.1 & 5 & 20.9 & 5 & 19.0 & 9 \\
\hline MHN 322-49 & 55 & 20.8 & 2 & 21.4 & 2 & 19.1 & 10 \\
\hline PR1165-3 & 68 & 22.1 & 20 & 21.4 & 20 & 20.1 & 21 \\
\hline 'Bella' & 70 & 21.9 & 16 & 21.7 & 16 & 19.3 & 15 \\
\hline PR1418-15 & 71 & 22.0 & 19 & 21.1 & 19 & 19.4 & 17 \\
\hline PR1483-105 & 72 & 21.9 & 17 & 21.6 & 17 & 20.1 & 22 \\
\hline SEF 16 & 92 & 21.7 & 14 & 21.6 & 14 & 18.8 & 6 \\
\hline SER 118 & 98 & 21.6 & 12 & 21.1 & 12 & 18.4 & 3 \\
\hline 'Rojo Chortí' & 102 & 20.7 & 1 & 21.1 & 1 & 17.7 & 1 \\
\hline SB2-170 & 109 & 21.9 & 18 & 20.6 & 18 & 19.1 & 11 \\
\hline TARS-LFR1 & 110 & 21.5 & 7 & 21.3 & 7 & 17.9 & 2 \\
\hline TARS-MST1 & 111 & 22.4 & 23 & 21.4 & 23 & 18.7 & 5 \\
\hline 'Verano' & 117 & 21.4 & 6 & 21.4 & 6 & 18.7 & 4 \\
\hline 'Sankara' & 118 & 22.3 & 21 & 21.1 & 21 & 20.1 & 20 \\
\hline
\end{tabular}

BASE 120 trials planted in June were exposed to moderate levels of heat stress throughout the growing season. Given the projections for climate change in Central America and the Caribbean, it would be appropriate for bean breeders in the region to routinely screen bean lines under warmer than currently normal temperatures.

The oxisol at the Isabela Substation has proven to be a useful site for screening beans for adaptation to low soil fertility (Dorcinvil et al., 2010). In four of the five BASE 120 trials soil nitrate levels were sub-optimum. In Colorado, USA soils having nitrate levels $<11$ are recommended to be fertilized for dry bean production at a rate of $67.25 \mathrm{~kg} \mathrm{ha}^{-1}$ of $\mathrm{N}$ (Davis \& Brick, 2009).

Indirect selection for increased symbiotic nitrogen fixation can be successful on low $\mathrm{N}$ soils that are not fertilized (Bliss, 1993). Bean breeders in Central America and the Caribbean should regularly evaluate the performance of bean lines in unfertilized field trials.

Seed yield from the most promising lines from the BASE 120 trial were as great or greater than the mean seed of beans in Central America and the Caribbean (Food and Agriculture Organization, 2019). Several of the lines with superior performance in the unfertilized trials planted at Isabela, Puerto Rico possess additional traits of economic importance. SB2-170, a line that combined superior seed yield and non-significant GxE across environments, was selected for broad adaptation through a shuttle breeding program between the USDA-ARS in Puerto Rico and the University of Nebraska (McClean et al., 2011). Another line that combined a mean seed yield $>1,000 \mathrm{~kg} \mathrm{ha}^{-1}$ and 
non-significant G×E across growing seasons was the small red TARS-LFR1. This line was selected in Puerto Rico for resistance to root rot and common bacterial blight, and for SNF and adaptation to low fertility soils (Porch et al., 2014).

In soils that are deficient in $\mathrm{N}$, root growth and development, and SNF are favored to expand the capacity to acquire nutrients (Oldroyd \& Leyser, 2020). The ability of Hermosa to produce superior seed yield, while having poor nodulation scores and low \%NDFA, suggests that this black bean cultivar has the capacity to better utilize available soil nutrients. Beans can use different mechanisms to improve acquisition and efficiency of use of soil $\mathrm{N}$ (Dorcinvil et al., 2010). Increased efficiency of nutrient acquisition or use would contribute sustainably to increased bean seed yield (Beebe et al., 2012).

Mean BRGA of the lines in this study were intermediate in magnitude. Soybean [Glycine max L. (Merr.)] plants with roots having intermediate (40-60\%) BRGA were reported to be well-suited for acquiring both soil water and nutrients (Zhao, 2004).

SNF is sensitive to abiotic stresses including drought, low soil fertility and high temperatures (Beebe et.al., 2012). However, differences between bean genotypes in their SNF response to drought (Devi et al., 2013) and higher temperature (Fernández-Toledo et al., 1997) have been reported. Four of the five highest-yielding bean lines had three-year averages of \%NDFA $>50 \%$ which is greater than estimates of \%NDFA for common bean in most trials conducted in different regions of the world where this grain legume is produced (Peoples, 2009). One study reported a mean \%NDFA of $45.5 \%$ in a subset of 259 lines of the Andean Diversity Panel evaluated in Michigan, USA (Kamfwa et al., 2015). In Ontario Canada, Wilker et al. (2019) obteined a mean \%NDFA among Middle American bean lines to be $62.2 \%$. However, daylengths are longer, nights are cooler and net Fs may be greater at higher latitudes, which may favor SNF.

Pedigrees of the BASE 120 lines show that a large amount of genetic diversity was used to develop the elite Mesoamerican race bean lines in this study. It was possible to identify lines in this study that combined disease resistance with superior SNF. Breeding lines and cultivars that combine superior symbiotic nitrogen fixation and resistance to diseases including anthracnosis, common blight and BCMV have been identified (Wilker et al., 2019).

Although some of the elite lines in this study did not perform well in the low $\mathrm{N}$ soil at Isabela, Puerto Rico, they possess traits that may be useful as parents to develop cultivars for CAC. For example, the small red line SER 118 has yielded well and expressed greater yield efficiency in soils in Colombia having moderate levels of low P stress (Beebe et al., 2008) and terminal drought (Chaves-Barrantes et al., 2018). SEF 16 has resistance to BGYMV and has performed well in terminal drought and greater than optimum night temperatures (Chaves-Barrantes, 2015).

Carbon isotope discrimination $\left(\Delta^{13} \mathrm{C}\right)$ provides an indirect measure of water use efficiency in bean plants (Beebe et al., 2013). There were significant differences for $\Delta^{13} \mathrm{C}$ among entries and season $\times$ entry least square means were significant for all genotype $\times$ season combinations. Reduced SNF under drought associated with lower water use efficiency has been reported (Fenta et al., 2020). 'Rojo Chortí' was released in El Salvador (ParadaCardona et al., 2015) and in Honduras (Rosas et al., 2019) as a heat and drought tolerant small red bean cultivar. Greater water use efficiency was associated with bean genotypes having lower $\Delta^{13} \mathrm{C}$ values and greater harvest index (Sanz-Saez et al., 2019). The $\Delta{ }^{13} \mathrm{C}$ values reported on Mesoamerican beans planted in field trials in Ontario, Canada in 2011 and 2012 were greater than the $\Delta{ }^{13} \mathrm{C}$ values in this study (Farid and Navabi, 2015). The lowest $\Delta{ }^{13} \mathrm{C}$ estimate was 24.58 in Canada and the highest $\Delta^{13} \mathrm{C}$ value in this study was 22.4. Except for one location, where a negative association between $\Delta^{13} \mathrm{C}$ and \%NFDA has been reported (Farid \& Navabi, 2015).

This study identified elite Mesoamerican bean lines that possess unique combinations of traits that could be recombined in a breeding program to produce cultivars with superior ability to cope with biotic and abiotic constraints facing bean producers in Central America and the Caribbean. For example, the white bean cultivar 'Bella' had the highest overall seed yield and resistance to BGYMV, BCMNV, and common bacterial blight (Beaver et al., 2008). 'Bella' also produced more nodules and had estimates of \%NDFA $>50 \%$. The small red cultivar 
'Rojo Chortí' combines BGYMV and BCMV resistance and tolerance to heat. Its low $\Delta^{13} \mathrm{C}$ suggests that 'Rojo Chortí' may also have characteristics that favor better adaptation to drought. Plants possess different mechanisms to adapt to soils deficient in nutrients (Oldroyd \& Leyser, 2020). The black bean line 'Hermosa' produced superior seed yield despite having poor nodulation and a low estimated \%NDFA. This line may possess characteristics that contribute to more efficient acquisition or utilization of available soil nutrients.

Lines of diverse genetic background were identified in this study that had superior SNF, thus additional cycles of recombination and selection may produce progenies with improved SNF characteristics. Using parents having different traits that were expected to contribute to symbiotic nitrogen fixation, recurrent selection in a controlled environment for increased nodule number of common bean lines was successful (Pereira et al., 1993). Recurrent selection to increase seed yield and shoot and seed $\mathrm{N}$ accumulation in a low $\mathrm{N}$ soil in Minnesota was also effective (Elisondo-Barron et al., 1999). Much of the progress was attributed to enhanced SNF. The authors recommended advancing lines to at least the $\mathrm{F}_{4}$ generation to increase the frequency of lines having desirable combinations of traits and to allow evaluation in replicated trials. Most breeding programs in Central America and the Caribbean have low $\mathrm{N}$ sites that could be used to routinely screen bean advanced generation breeding lines for greater SNF. Another study reported that both shoot dry weight and shoot $\mathrm{N}$ and seed yield and seed $\mathrm{N}$ have been reported to be highly correlated ( $r>0.9$ ) (Elisondo-Barron et al., 1999). Therefore, evaluating bean lines for seed yield, biomass and days to maturity in a low $\mathrm{N}$ soil may provide an adequate preliminary screening for SNF. Indirect measures of biomass production using canopy reflectance indices (Gutiérrez-Rodríguez et al., 2006) would facilitate the screening of bean lines for this trait.

\section{Conclusions}

This study identified elite Mesoamerican bean lines from the Bean Abiotic Stress Evaluation (BASE 120) panel with superior performance and enhanced symbiotic nitrogen fixation (SNF) in an unfertilized soil at Isabela, Puerto Rico. The pedigrees show that a wide array of genetic diversity was used to develop the elite lines in the BASE 120 panel and that many of these lines possess resistances to several of the most important biotic and abiotic factors limiting bean seed yield in Central America and the Caribbean (CAC). Bean breeders in CAC should be able to make use of this genetic diversity to continue to make significant progress developing improved Mesoamerican beans cultivars.

The occasional assembly, distribution and evaluation of regional nurseries containing elite Mesoamerican bean lines from different breeding programs could represent a valuable resource for bean breeding programs in Central America and the Caribbean. A regional nursery could also include the best sources of resistance to major biotic and abiotic constraints from other races and gene pools of the common bean. As technologies such as the molecular SNP assays become more accessible and cost-effective, Mesoamerican bean breeding programs should be able to utilize marker-assisted selection to introgressive genes of economic importance into Mesoamerican bean breeding lines.

\section{Acknowledgement}

The authors wish to thank Dr. Juan Carlos Rosas for providing Zamorano bean lines and cultivars and for his valuable contributions during the preparation of the manuscript. 


\section{References}

Abrahão, S. A., de Assis de Carvalho Pinto, F., Marçal de Queiroz, D., Terra Santos, N., \& Eustáquio de Souza Carneiro, J. (2013). Determination of nitrogen and chlorophyll levels in bean-plant leaves by using spectral vegetation bands and indices. Revista Ciência Agronômica, 44(3), 464-473. https://doi.org/10.1590/S1806-66902013000300007

Akter, Z., Pageni, B. B., Lupwayi, N. Z., \& Balasubramanian, P. M. (2018). Biological nitrogen fixation by irrigated dry bean (Phaseolus vulgaris L.) genotypes. Canadian Journal of Plant Science, 98(5), 1159-1167. https://doi.org/10.1139/ cjps-2017-0301

Beaver, J. S., Estévez De Jensen, C., Lorenzo-Vázquez, G., González, A., Martínez, H., \& Porch, T. G. (2018a). Registration of 'Bella' white-seeded common bean cultivar. Journal of Plant Registrations, 12(2), 190-193. https://doi.org/10.3198/ jpr2017.05.0029crc

Beaver, J. S., Estévez de Jensen, C., Ruiz-Quiles, L., Vázquez, G., González, A., Martínez, H., \& Porch, T. G. (2018b). Release of 'Hermosa' black bean cultivar. Journal of Agriculture of the University of Puerto Rico, 102(1-2), 123-128. https:// doi.org/10.46429/jaupr.v102i1-2.17540

Beaver, J. S., Godoy-Lutz, G., Steadman, J. R., \& Porch, T. G. (2011). Release of 'Beníquez’ white bean (Phaseolus vulgaris L.) cultivar. Journal of Agriculture of the University of Puerto Rico, 95(3), 237-240. https://doi.org/10.46429/jaupr. v95i3-4.2579

Beaver, J. S., Porch, T. G., \& Zapata, M. (2008). Registration of 'Verano' white bean. Journal of Plant Registrations, 2(3), 187-189. https://doi.org/10.3198/jpr2008.02.0110crc

Beaver, J. S., Prophete, E. H., Rosas, J. C., Godoy Lutz, G., Steadman, J. R., \& Porch, T. G. (2014). Release of 'XRAV-40-4' black bean (Phaseolus vulgaris L.) cultivar. Journal of Agriculture of the University of Puerto Rico, 98(1), 83-87. https://doi.org/10.46429/jaupr.v98i1.224

Beaver, J. S., Rosas, J. C., Myers, J., Acosta, J., Kelly, J. D., Nchimbi-Msolla, S., Misangu, R., Bokosi, J., Temple, S., ArnaudSantana, E., \& Coyne, D. P. (2003). Contributions of the Bean/Cowpea CRSP to cultivar and germplasm development in common bean. Field Crops Research, 82, 87-102. https://doi.org/10.1016/S0378-4290(03)00032-7

Beebe, S., Rao, I. M., Blair, M. W., \& Acosta-Gallegos, J. A. (2013). Phenotyping common beans for adaptation to drought. Frontiers in Physiology, 4, Article 35. https://doi.org/10.3389/fphys.2013.00035

Beebe, S. E., Rao, I. M., Cajiao, C., \& Grajales, M. (2008). Selection for drought resistance in common bean also improves yield in phosphorus limited and favorable environments. Crop Science, 48(2), 582-592. https://doi.org/10.2135/ cropsci2007.07.0404

Beebe, S. E., Rao, I. M., Mukankusi, C., \& Buruchara, R. A. (2012). Improving resource use efficiency and reducing risk of common bean production in Africa, Latin America, and the Caribbean. In C. H. Hershey (Ed.), Eco-Efficiency: From vision to reality (pp. 117-134). Centro Internacional de Agricultura Tropical (CIAT).

Bliss, F. A. (1993). Breeding common bean for improved biological. Plant and Soil, 152, 71-79. https://doi.org/10.1007/97894-011-2100-2_6

Centro Nacional de Tecnología Agropecuaria y Forestal. (2005). CENTA Pipil variedad de frijol rojo resistente al virus de mosaico dorado amarillo y tolerante al calor [Boletín Técnico]. Ministerio de Agricultura y Ganadería. 
Chaves-Barrantes. N. F. (2015). Uso de recombinantes de Phaseolus vulgaris L., P. coccineus L. y P. acutifolius A. Gray para mejorar la tolerancia del frijol común a diferentes tipos de estrés abiótico [Tesis de Doctorado, no publicada]. Universidad Nacional de Colombia.

Chaves-Barrantes, N. F., Polanía, J. A., Muñoz-Perea, C. G., Rao, I. M., \& Beebe, S. E. (2018). Caracterización fenotípica por resistencia a sequía terminal de germoplasma de frijol común. Agronomía Mesoamericana, 29(1), 1-17. https://doi. org/10.15517/ma.v29i1.27618

Davis, J. G., \& Brick, M. A. (2009). Fertilizing dry beans (Fact Sheet No. 0.539). Colorado State University Extension. https:// extension.colostate.edu/docs/pubs/crops/00539.pdf

Devi, M. J., Sinclair, T. R., Beebe, S. E., \& Rao, I. M. (2013). Comparison of common bean (Phaseolus vulgaris L.) genotypes for nitrogen fixation tolerance to soil drying. Plant and Soil, 364, 29-37. https://doi.org/10.1007/s11104-012-1330-4

Dorcinvil, R., Sotomayor-Ramírez, D., \& Beaver, J. S. (2010). Agronomic performance of common bean (Phaseolus vulgaris L.) lines in an Oxisol. Field Crops Res, 118(3), 264-272. https://doi.org/10.1016/j.fcr.2010.06.003

Elisondo-Barron, J., Pasini, R. J., Davis, D. W., Stuthman, D. D., \& Graham, P. H. (1999). Response to selection for seed yield and nitrogen $\left(\mathrm{N}^{2}\right)$ fixation in common bean (Phaseolus vulgaris L.). Field Crops Research, 62(2-3), 119-128. https:// doi.org/10.1016/S0378-4290(99)00009-X

Food and Agriculture Organization. (2019). Crops/2017/Dry beans/Yield/Dominican Republic, Haiti, Guatemala, El Salvador, Honduras and Nicaragua. http://www.fao.org/faostat/en/\#data/QC

Farquhar, G. D., Ehleringer, R., \& Hubic, K. T. (1989). Carbon isotope discrimination and photosynthesis. Annual Review of Plant Physiology and Plant Molecular Biology, 40, 503-37. https://doi.org/10.1146/annurev.pp.40.060189.002443

Farid, M., Earl, H. J., Pauls, K. P., \& Navabi, A. (2017). Response to selection for improved nitrogen fixation in common bean (Phaseolus vulgaris L.). Euphytica, 213(4), 99-111. https://doi.org/10.1007/s10681-017-1885-5

Farid, M., \& Navabi, A. (2015). $\mathrm{N}_{2}$ fixation ability of different dry bean genotypes. Canadian Journal of Plant Science, 95(6), 1243-1257. https://doi.org/10.4141/cjps-2015-084

Fenta, B. A., Beebe, S. E., \& Kunert, K. J. (2020). Role of fixing nitrogen in common bean growth under water deficit conditions. Food Energy Security, 9, Article e183. https://doi.org/10.1002/fes3.183

Fernández-Toledo, F., Beaver, J. S., \& Schroder, E. (1997). Nodulation and seed yield of common bean in moderate and high temperature environments. Department of Agronomy and Soils, University of Puerto Rico. https://naldc.nal.usda.gov/ download/IND20600830/PDF

Graham, P. H., Rosas, J. C. Estevez de Jensen, C., Peralta, E., Tlusty, B., Acosta-Gallegos, J., \& Arraes Pereira, P. A. (2003). Addressing edaphic constraints to bean production: The Bean/Cowpea CRSP project in perspective. Field Crops Research, 82(2-3), 179-192. https://doi.org/10.1016/S0378-4290(03)00037-6

Granadino-Espinal, M. A., \& León-Gonzalez, O. H. (2016). Evaluación de frijol común (Phaseolus vulgaris L.) por su tolerancia a suelos de baja fertilidad (Tesis de Licenciatura, Escuela Agrícola Panamericana). Repositorio del Zamorano. http:// bdigital.zamorano.edu/bitstream/11036/5851/1/CPA-2016-T055.pdf

Gutiérrez-Rodríguez, M., Escalante-Estrada, J. A., Rodriguez Gonzalez, M. T., \& Reynolds, M. P. (2006). Canopy reflectance indices and its relationship with yield in common bean plants (Phaseolus vulgaris L.) with phosphorous supply. International Journal of Agriculture \& Biology, 8(2), 203-207. 
Heilig, J. A, Beaver, J. S., Wright, E. M., Song, Q., \& Kelly, J. D. (2017). QTL analysis of symbiotic nitrogen fixation in a black bean population. Crop Science, 57(1), 118-129. https://doi.org/10.2135/cropsci2016.05.0348

Herridge, D. F., Peoples, M. B., \& Boddey, R. M. (2008). Global inputs of biological nitrogen fixation in agricultural systems. Plant Soil, 311, 1-18. https://doi.org/10.1007/s11104-008-9668-3

Instituto de Ciencia y Tecnología Agrícolas. (2010). Nuevas variedades de frijol ICTA Petén e ICTA Sayaxché [Brochure]. Instituto de Ciencia y Tecnología Agrícolas. http://arsftfbean.uprm.edu/bean/wp-content/uploads/2020/02/ICTAPeten-ACM-e-ICTA-Sayaxche_Nuevas-variedades-de-frijol-para-el-Peten-2010.pdf

Kamfwa, K., Cichy, K. A., \& Kelly, J. D. (2015). Genome-wide association analysis of symbiotic nitrogen fixation in common bean. Theoretical and Applied Genetics, 128(10), 1999-2017. https://doi.org/10.1007/s00122-015-2562-5

Liao, H., Rubio, G., Yan, X., Cao, A., Brown, K. M., \& Lynch, J. P. (2001). Effect of phosphorus availability on basal root shallowness in common bean. Plant and Soil, 232(2-3), 69-79. https://doi.org/10.1023/A:1010381919003

McClean, P. E., Burridge, J. Beebe, S. Rao, I. M., \& Porch, T. G. (2011). Crop improvement in the era of climate change: an integrated, multi-disciplinary approach for common bean (Phaseolus vulgaris L.). Functional Plant Biology, 38, 927-933. https://doi.org/10.1071/FP11102

Miklas, P. N., Kelly, J. D., Beebe, S. E., \& Blair, M. W. (2006). Common bean breeding for resistance against biotic and abiotic stresses: From classical to MAS breeding. Euphytica, 147, 105-131. https://doi.org/10.1007/s 10681-006-4600-5

National Centers for Environmental Information. (2020). Comparative climatic data. https://www.ncdc.noaa.gov/ghcn/ comparative-climatic-data

Oladzad, A., Porch, T. G., Rosas, J. C., Mafi Moghaddam, S., Beaver, J. S., Beebe, S. E., Burridgw, J., Nhaguapana, C., Amade, M., Miklas, P. N., Ratz, B., White, J. W., Lynch, J., \& McClean, P. E. (2019). Single and multi-trait GWAS identify genetic factors associated with production traits in common bean under abiotic stress environments. Genes / Genomes / Genetics (G3), 9(6), 1881-1892. https://doi.org/10.1534/g3.119.400072

Oldroyd, G. E. D., \& Leyser, O. (2020). A plant's diet, surviving in a variable nutrient environment. Science, 368(6486), Article eaba0196. https://doi.org/10.1126/science.aba0196

Parada-Cardona, J. R., Ventura-Elías, R., Clará, A., \& Bruno, O. (2015). 'CENTA EAC' variedad de frijol color rojo claro [Brochure]. Nacional de Tecnología Agropecuaria y Forestal (CENTA). http://arsftfbean.uprm.edu/bean/wp-content/ uploads/2020/02/CENTA-EAC-nueva-variedad-de-frijol-rojo-claro-2015.pdf

Peoples, M. B., Brockwell, J., Herridge, D. F., Rochester, I. J., Alves, B. J. R., Urquiaga, S., Boddey, R. M., Dakora, F. D., Bhattarai, S., Maskey, S. L., Sampet, C., Rerkasem, B., Khan, D. F., Hauggaard-Nilsen, H., \& Jensen, E. S. (2009). The contributions of nitrogen-fixing crop legumes to the productivity of agricultural systems. Symbiosis, $48,1-17$. https://doi.org/10.1007/BF03179980

Pereira, P. A. A., \& Bliss, F. A. (1987). Nitrogen fixation and plant growth of common bean (Phaseolus vulgaris L.) at different levels of phosphorus availability. Plant Soil, 104, 79-84. https://doi.org/10.1007/BF02370628

Pereira, P. A. A., Miranda, B. D., Attewell, J. R., Kmiecik, K. M., \& Bliss, F. A. (1993). Selection for increased nodule number in common bean (Phaseolus vulgaris L.). Plant and Soil, 148, 203-209. https://doi.org/10.1007/BF00012858 
Polania, J. A., Poschenrieder, C., Beebe, S., \& Rao, I. M. (2016a). Effective use of water and increased dry matter partitioned to grain contribute to yield of common bean improved for drought resistance. Frontiers in Plant Science, 7, Article 660. https://doi.org/10.3389/fpls.2016.00660

Polania, J., Poschenrieder, C., Rao, I. M., \& Beebe, S. (2016b). Estimation of phenotypic variability in symbiotic nitrogen fixation ability of common bean under drought stress using ${ }^{15} \mathrm{~N}$ natural abundance in grain. European Journal of Agronomy, 79, 66-73. https://doi.org/10.1016/j.eja.2016.05.014

Porch, T. G., Beaver, J. S., Abawi, G., Estévez de Jensen, C., \& Smith, J. R. (2014). Registration of a small-red dry bean germplasm, TARS LFR1, with multiple disease resistance and superior performance in low nitrogen soils. Journal of Plant Registrations, 8(2), 177-182. https://doi.org/10.3198/jpr2013.03.0015crg

Porch, T. G., Urrea, C. A., Beaver, J. S., Valentin, S., Peña and P. A., \& Smith, J. R. (2012). Registration of TARS-MST1 and SB-DT1 multiple stress-tolerant black bean germplasm. Journal of Plant Registrations, 6(1), 75-80. https://doi. org/10.3198/jpr2010.08.0501crg

Rosas, J. C. (2011). Contribuciones del programa de investigaciones en frijol en Centro América y El Caribe. CEIBA, 52(1), 65-73. https://doi.org/10.5377/ceiba.v52i1.967

Rosas, J. C. (2015). Paraisito Mejorado 2 (PM2- Don Rey) [Brochure]. Escuela Agrícola Panamericana. http://www. programafpma.com/PDF/variedades/honduras/06PM2DonRey.pdf

Rosas, J. C., Beaver, J. S., Escoto, D., Perez, C. A., Llano, A., Hernández, J. C., \& Araya, R. (2004). Registration of 'Amadeus 77' small red common bean. Crop Science, 44, 1867-1868. https://doi.org/10.2135/CROPSCI2004.1867

Rosas, J.C., Castro, A., \& Flores, E. (2000). Mejoramiento genético del frijol rojo y negro Mesoamericano para Centroamérica y el Caribe. Agronomía Mesoamericana, 11(2), 37-46. https://doi.org/10.15517/am.v11i2.17305

Rosas, J. C., Escoto, D., \& Meza, N. (2016). Propuesta de liberación de las variedades de frijol de grano negro 'Azabache 40’ y 'Lenca precoz'. Comité Nacional de Liberación de Variedades e Híbridos Vegetales, Dirección de Ciencia y Tecnología Agropecuaria (DICTA). http://dicta.gob.hn/files/Frijol-2016-011.pdf

Rosas, J. C., Rodriguez, I. Y., Escoto, N. D., \& Meza, N. (2019). Propuesta de liberación de la variedad de frijol "Rojo Chortí". Dirección de Ciencia y Tecnología Agropecuaria (DICTA). http://dicta.gob.hn/files/Frijol-2016-012.pdf

Sanz-Saez, A., Maw, M. J. W., Polania, J. A., Rao, I. M., Beebe, S. E., \& Fritschi, F. B. (2019). Using carbon isotope discrimination to assess genotypic differences in drought resistance of parental lines of common bean. Crop Science, 59(5), 2153-2166. https://doi.org/10.2135/cropsci2019.02.0085

Unkovich, M., Herridge, D., Peoples, M., Cadisch, G., Boddey, B., Giller, K., Alves, B., \& Chalk, P. (2008). Measuring plant-associated nitrogen fixation in agricultural systems (ACIAR Monograph Series 136). Australian Centre for International Agricultural Research (ACIAR). https://aciar.gov.au/publication/books-and-manuals/measuring-plantassociated-nitrogen-fixation-agricultural-systems

van Schoonhoven, A., \& Pastor-Corrales, M. A. (1987). Standard system for the evaluation of bean germplasm. Centro Internacional de Agricultura Tropical (CIAT).

Villar-Sánchez, B., López-Salinas, E., Tosquy-Valle, O. H., \& Cruz-Chávez, F. J. (2010). Rojo INIFAP, Nueva variedad de frijol de grano rojo para el trópico de México. Revista Mexicana de Ciencias Agrícolas, 1(5), 681-686. http://www.scielo. org.mx/pdf/remexca/v1n5/v1n5a6.pdf 
Wilker, J., Navabi, A., Rajcan, I., Marsolais, F., Hill, B., Torkamaneh, D., \& Peter Pauls, K. (2019). Agronomic performance and nitrogen fixation of heirloom and conventional dry bean varieties under low-nitrogen field conditions. Frontiers in Plant Science, 10, Article 952. https://doi.org/10.3389/fpls.2019.00952.

Zhao, J., Fu, J., Liao, H., He, Y., Nian, H., Hu, Y., Qiu, L., Dong, Y., \& Yan, X. (2004). Characterization of root architecture in an applied core collection for phosphorus efficiency of soybean germplasm. Chinese Science Bulletin, 49, 1611-1620. https://doi.org/10.1007/BF03184131 